\title{
Impact of Demonetization Process on the Performance of Nifty
}

\author{
Prof. Mohd. Shamim \\ Department of Commerce, Aligarh Muslim University, Aligarh, 202001, UP, India
}

\begin{abstract}
Received: 12.06.2021 •
Abstract: This paper investigates the impact of demonetization process on the performance of Nifty 50 and its Sectorial Indices. The study uses data of closing prices from 28 June 2016 up to 20 March 2017. The study employs descriptive statistics, paired sample T test and ANOVA to evaluate the impact of demonetization process on the performance of Nifty 50 and its Sectorial Indices. It has found that there is statistical significance at the level of 5\% that Nifty 50 dropped after the demonetization event as compared to the pre demonetization event. Further, the results reveal that most of Sectorial Indices of Nifty 50 sloped downward post demonetization event and the significance of the statistical results are varied from one sector to another. It is recommended that periodic review of the policy should be made to iron out the negative impacts of demonetization. Also, it is imperative to evaluate the impact of demonetization on the short, medium, and long run to avoid any grey areas for any future policy regarding cashless economy or demonetization.
\end{abstract}

Keywords: Demonetization, Cashless, NSE, Nifty, Sectorial Indices.

\section{Introduction}

On 31 March 2016, the annual report of Reserve Bank of India declared that total bank notes in circulation is Rs. 16.42 lakh crore (US $\$ 240$ billion). Nearly $86 \%$ of the notes (i.e. Rs. 14.18 lakh crore (US $\$ 210$ billion)) was 1000 and 500 rupee notes (Singh \& Singh, 2016). On November 8, 2016, the government announced that except for a few specified purposes, the two largest denomination notes, Rs 500 and Rs 1000, were "demonetized" with immediate effect, ceasing to be legal tender. Restrictions were placed on the convertibility of the ceased notes, bank deposit and cash withdrawals. The ceased notes were to be deposited in the banks by December 30, 2016 (Government of India, Ministry of Finance, Department of Economic Affairs, 2017). The proposal by the government aimed to elimination of ceased notes from circulation and replacement them gradually with a new set of note (National Institute of Public Finance and Policy New Delhi, 2016). The aim of the action was fourfold: to curb corruption; counterfeiting; the use of high denomination notes for terrorist activities; and especially the accumulation of "black money", generated by income that has not been declared to the tax authorities (Governmant of India, Ministry of Finance, 2017).

Despite of huge increase in plastic cards and digital transactions in recent years, the currency in circulation as a proportion of GDP (gross domestic product) in India is the highest among emerging economies. The currency-GDP ratio stood at 10.6\% at the end of March 2016, the highest in 16 years. In fact, India has the highest currency-GDP ratio among BRICS (Brazil, Russia, India, China, and South Africa) nations (M Allirajan, 2017). Accordingly, that demonization event which took place on 8 November 2016 may affect many aspects of the Indian economy as India depends on cash economy and the currency-GDP ratio is high compared to other countries. 
Indian stock market has gained the interest of investors investing in two main stock market named as Bombay Stock Exchange (BSE) and National Stock Exchange (NSE). The Sensex and NIFTY are two such prominent market indices that function within the Indian stock market. These two market indexes represent the stocks for BSE (Bombay Stock Exchange) and NSE (National Stock Exchange) respectively (Bhardwaj, Narayan, Vanraj, Pawan, \& Dutta, 2015). The NIFTY 50 is a diversified 50 stock index accounting for 13 sectors of the economy. It is used for a variety of purposes such as benchmarking fund portfolios, index based derivatives and index funds. It represents about $65 \%$ of the free float market capitalization of the stocks listed on NSE as on March 31,2016. Its total traded value constituents approximately $46 \%$ of the traded value of all stocks on the NSE for the last six months ending March 2016 (NSE, 2017). So there is a need to investigate the impact of demonetization process by using these very important index i.e Nifty 50 .

Review of related literatures show lack of comprehensive empirical studies regarding the impact of demonetization process on the stock markets in India since the introduction of the Cashless economy policy on 8 November 2016. Further, with dearth of imperial studies on the impact of demonization on many aspects of the Indian economy; academic research has not yet covered the impact of demonetization on the Indian economy. Majority of studies conducted in India to investigate the impact of demonization are descriptive and theoretical studies. Few studies conducted on the impact of demonization in some other countries like Nigeria, Brazil, and some other countries but the results of these studies can't be drown to the Indian scenario as India has its own specific factors.

This study aims to investigate empirically the impact of demonetization process on the stock market in India represented by Nifty 50. In order to explore the impact of demonetization process on Nifty 50 and its sectorial indices, this paper is organized as follows. Section two demonstrates the literature review. Section three provides the objectives of the study. Section four presents the hypotheses of the study. Section five outlines the methodology. Section six discusses the descriptive statistics and results of the empirical tests. Section seven concludes and presents the implications and limitations of the study.

\section{Literature Review}

Chelladurai \& V.Sornaganesh (2016) theoretically studied the impact of demonetization on many aspects including; society, Stock market, Non-Banking Finance Companies, Professionals, ecommerce Industry, FMCG and on SME. The study concluded that demonetization was a good move which will have a large impact on India and will reduce black money, but some challenges faced by citizens due to demonetization process. Similarly, National Institute of Public Finance and Policy, New Delhi (2016) in a working paper of Impact demonetization on the Economy sated that it is imperative to evaluate the short run and medium- term impacts that such a shock is expected to have on the economy. Further, Kaur (2017) studied the impact of demonetization on cashless payment system, electronic payment system. The study concluded that demonetization affects the economy through the liquidity side. In the same quest, (Singh \& Singh 2016) studied the impact of demonetization on Indian economy. The study discussed the experience of impact of demonetization in some countries, and on Indian economy. The study stated that probable consequences of the demonetization, if the money finds its way in the economy it could have a meaningful impact. The study also argued that experiences from different countries shows that the move was one of the series that failed to fix a debt-burdened and inflation-ridden economy.

Some studies conducted in Nigeria to assess the impact of cashless economy on different aspects. Ovat (2012), Mieseigha \& Ogbodo (2013), Ejiofor \& Rasaki (2012), and Odior \& Banuso (1857) studied the benefits and challenges of cashless economy in Nigeria. They agree that the cashless economy has 
a positive impact on economy development, and beneficial though it comes with high level of concerns over security and management of cost savings resulting from

its implementation. Further, they advocate that a positive and significant relationship between cashless economy and transparency, accountability and reduction cash-related fraud, but periodic review of the policy by the $\mathrm{CBN}$ to iron out grey areas; embarking on intensive awareness campaign and sensitization of the citizenry by the $\mathrm{CBN}$; putting adequate security mechanisms in place to forestall fraudulent practices; making the public power supply work efficiently; and exempting cash lodgments and public holidays from cash management charges.

In another context, Emengini \& Alio (2014) studied the impact of cashless economy on financial statement reporting. They found that Stakeholders in the financial statements of corporate entities place more credence on financial statements emanating from cashless-based economies because of its effect on reduced tax evasion, inflation and revenue leakages, easier to comply with auditing standards and effective performance of business transactions. Further, Bayero (2015) studied the impact of cashless economy on financial inclusion in Nigeria. The study revealed that awareness, consumer/user value proposition, and Infrastructure were found to have strong significant relationship with Financial Inclusion while Business Model of Financial Service Providers did not show any significant relationship with Financial Inclusion.

Some other studies conducted in different countries to assess the impact of cashless economy on many aspects (Adu 2016; Ezeamama et al. 2014; Osazevbaru \& Yomere 2015; Muyiwa et al. 2013; Olelewe \& E. 2014; Matthew \& Anyanwaokoro 2016; Okoye \& Ezejiofor 2013; Muhibudeen \& Haladu 2015; Worthington, 2014) They argue that the cashless policy offers immense benefits to the economy, banking sector, development of payment system, reduce cash related robbery thereby reducing risk of carrying cash, and attract more foreign investors to the country. But Prior studies conducted in India and some other countries have not yet investigated the impact of demonetization process on the stock markets.

Following is a table (1) summarizing some prior studies which investigated cashless economy and / or demonetization in India and some other countries. 
Table 1. Literature Review on Demonetization and Cashless Economy

\begin{tabular}{|c|c|c|c|c|c|c|c|c|c|}
\hline \multirow[b]{2}{*}{ No } & \multirow[b]{2}{*}{ Studies } & \multirow[b]{2}{*}{ country } & \multirow[b]{2}{*}{ Journal } & \multirow[b]{2}{*}{ Variables } & \multicolumn{3}{|c|}{ Sample } & \multirow{2}{*}{$\begin{array}{l}\text { Methods } \\
\text { And Applied } \\
\text { Tests }\end{array}$} & \multirow[b]{2}{*}{ Results } \\
\hline & & & & & Size & $\begin{array}{l}\text { Time } \\
\text { limit }\end{array}$ & Data & & \\
\hline 1 & $\begin{array}{l}\text { (Chelladurai \& V.Sornaganesh, } \\
\text { 2016) Demonetisation, Unified } \\
\text { Payment Interface \& Cashless } \\
\text { Economy }\end{array}$ & India & $\begin{array}{l}\text { International } \\
\text { Journal of } \\
\text { Informative \& } \\
\text { Futuristic } \\
\text { Research }\end{array}$ & $\begin{array}{l}\text { impact of demonetisation on the } \\
\text { society, Stock market, Non-Banking } \\
\text { Finance Companies, Professionals, } \\
\text { FMCG, SME sector, and e-commerce } \\
\text { Industry }\end{array}$ & N.A & N.A & N.A & $\begin{array}{l}\text { Descriptive } \\
\text { and } \\
\text { theoretical }\end{array}$ & $\begin{array}{l}\text { Citizens faced some challenges due to demonetisation } \\
\text { but it was a good move that may reduce black money } \\
\text { and has huge impact on India. }\end{array}$ \\
\hline 2 & $\begin{array}{l}\text { (Singh \& Singh, 2016) Impact of } \\
\text { Demonetization on Indian } \\
\text { Economy }\end{array}$ & India & $\begin{array}{l}\text { International } \\
\text { Journal of Science } \\
\text { Technology and } \\
\text { Management }\end{array}$ & $\begin{array}{l}\text { experience of impact of } \\
\text { demonetization in some countries, and } \\
\text { on Indian economy, probable } \\
\text { consequences of the demonetization }\end{array}$ & N.A & N.A & N.A & $\begin{array}{l}\text { Graph and } \\
\text { percentile }\end{array}$ & $\begin{array}{l}\text { Demonetization could have a meaningful impact on } \\
\text { India if the money finds its way in the economy }\end{array}$ \\
\hline 3 & $\begin{array}{l}\text { (Bayero, 2015) Effects of } \\
\text { Cashless Economy Policy on } \\
\text { Financial Inclusion in Nigeria: } \\
\text { An Exploratory Study }\end{array}$ & Nigeria & $\begin{array}{l}\text { Procedia-Social } \\
\text { and Behavioral } \\
\text { Sciences }\end{array}$ & $\begin{array}{l}\text { Cashless Economy Policy; } \\
\text { financial inclusion; electronic } \\
\text { payment; payment infrastructure; } \\
\text { awareness; customer value } \\
\text { proposition; business mode }\end{array}$ & 230 & N.A & $\begin{array}{l}\text { cross } \\
\text { sectional } \\
\text { survey }\end{array}$ & $\begin{array}{l}\text { Descriptive } \\
\text { statistics } \\
\text { regression }\end{array}$ & $\begin{array}{l}\text { Financial Inclusion have strong significant relationship } \\
\text { with Awareness, Infrastructure and Consumer but there } \\
\text { is no significant relationship with Business Model of } \\
\text { Financial Service Providers }\end{array}$ \\
\hline 4 & $\begin{array}{l}\text { (National Institute of Public } \\
\text { Finance and Policy New Delhi, } \\
2016) \text { Demonetisation : Impact } \\
\text { on the Economy }\end{array}$ & India & $\begin{array}{l}\text { National Institute } \\
\text { of Public Finance } \\
\text { and Policy, New } \\
\text { Delhi }\end{array}$ & $\begin{array}{l}\text { demonetization, cashless transactions, } \\
\text { credit, tax evasion }\end{array}$ & N.A & N.A & N.A & $\begin{array}{l}\text { Descriptive } \\
\text { and } \\
\text { theoretical }\end{array}$ & $\begin{array}{l}\text { Short run and medium-term impacts which expected to } \\
\text { affect the economy as a result of demonetization should } \\
\text { be evaluated }\end{array}$ \\
\hline 5 & $\begin{array}{l}\text { (Worthington, 2014) The } \\
\text { Cashless Society }\end{array}$ & Europe & $\begin{array}{l}\text { International } \\
\text { Journal of Retail } \\
\text { \& Distribution } \\
\text { Management }\end{array}$ & plastic payment & N.A & N.A & N.A & $\begin{array}{l}\text { Graph and } \\
\text { percentile }\end{array}$ & $\begin{array}{l}\text { a less cash society by plastic card will continue to grow } \\
\text { in popularity throughout Europe }\end{array}$ \\
\hline 6 & $\begin{array}{l}\text { (Emengini \& Alio, 2014) } \\
\text { Cashless Economy and Financial } \\
\text { Statement Reporting in Nigeria }\end{array}$ & Nigeria & $\begin{array}{l}\text { European Journal } \\
\text { of Accounting } \\
\text { Auditing and } \\
\text { Finance Research }\end{array}$ & $\begin{array}{l}\text { Cashless, Financial system, Financial } \\
\text { Reporting, Economy, Business } \\
\text { Transaction }\end{array}$ & N.A & N.A & $\begin{array}{l}\text { Questionnai } \\
\text { re and oral } \\
\text { interview }\end{array}$ & $\begin{array}{l}Z \text {-test } \\
\text { statistics and } \\
\text { Chi-square } \\
\text { \&secondary }\end{array}$ & $\begin{array}{l}\text { Stakeholders place more credence for financial } \\
\text { statements emanated from cashless economy because } \\
\text { they are more complied with auditing standards, } \\
\text { effective performance of business transactions, more } \\
\text { reduced tax evasion, and less revenue leakages. }\end{array}$ \\
\hline 7 & $\begin{array}{l}\text { (Adu, 2016) Cashless Policy and } \\
\text { its Effects on the Nigerian } \\
\text { Economy }\end{array}$ & Nigeria & $\begin{array}{l}\text { European Journal } \\
\text { of Business, } \\
\text { Economics and } \\
\text { Accountancy }\end{array}$ & $\begin{array}{l}\text { Information Technology, Computer, } \\
\text { Automated Teller Machine. positive } \\
\text { and negative effects of cashless policy }\end{array}$ & N.A & N.A & N.A & $\begin{array}{l}\text { Descriptive } \\
\text { and } \\
\text { theoretical }\end{array}$ & $\begin{array}{l}\text { Electronic banking as it requires commitment of huge } \\
\text { financial resources on telecommunication facilities, } \\
\text { constant electricity and computer technology but it has a } \\
\text { strong influence on the development of payment system. }\end{array}$ \\
\hline 8 & $\begin{array}{l}\text { (Kaur, 2017) Demonetization: } \\
\text { Impact on Cashless Payment } \\
\text { System }\end{array}$ & India & $\begin{array}{l}\text { International } \\
\text { Journal of Science } \\
\text { Technology and } \\
\text { Management }\end{array}$ & $\begin{array}{l}\text { Demonetization, Electronic Payment } \\
\text { System. }\end{array}$ & N.A & N.A & N.A & $\begin{array}{l}\text { Descriptive } \\
\text { and } \\
\text { theoretical }\end{array}$ & $\begin{array}{l}\text { Demonetization affects the economy through the } \\
\text { liquidity side }\end{array}$ \\
\hline 9 & $\begin{array}{l}\text { (Ezeamama et al., 2014) The } \\
\text { Impact of Central Bank of } \\
\text { Nigeria Cashless Policy in } \\
\text { Nigeria Economy }\end{array}$ & Nigeria & $\begin{array}{l}\text { IOSR Journal of } \\
\text { Business and } \\
\text { Management } \\
\text { (IOSR-JBM) }\end{array}$ & Cashless economy, Cashless policy & 500 & N.A & $\begin{array}{l}\text { Questionnai } \\
\text { re }\end{array}$ & $\begin{array}{l}\text { Graph and } \\
\text { percentile } \\
\text { Percentages }\end{array}$ & $\begin{array}{l}\text { cashless policy may curb cash related corruption, } \\
\text { reduce cash related robbery, therefore decrease risk of } \\
\text { carrying cash, attract more foreign investors, increase } \\
\text { employment }\end{array}$ \\
\hline 10 & $\begin{array}{l}\text { (Osazevbaru \& Yomere, 2015) } \\
\text { Benefitts and Challenges of } \\
\text { Nigeria's Cash-Less Policy }\end{array}$ & Nigeria & $\begin{array}{l}\text { Kuwait Chapter of } \\
\text { Arabian Journal of } \\
\text { Business and } \\
\text { Management } \\
\text { Review }\end{array}$ & $\begin{array}{l}\text { Economic reforms, Banking sector, } \\
\text { Payment channels, ATM, Payment } \\
\text { terminal }\end{array}$ & N.A & N.A & $\begin{array}{l}\text { secondary } \\
\text { data }\end{array}$ & $\begin{array}{l}\text { Descriptive } \\
\text { and } \\
\text { theoretical }\end{array}$ & $\begin{array}{l}\text { Cash-less policy offers huge benefits to the banking } \\
\text { sector whereas income based on cash-less setting is } \\
\text { higher than in cash based arrangement }\end{array}$ \\
\hline 12 & $\begin{array}{l}\text { (Muyiwa et al., 2013) Impact of } \\
\text { Cashless Economy in Nigeria }\end{array}$ & Nigeria & $\begin{array}{l}\text { Greener Journal of } \\
\text { Internet, }\end{array}$ & Cashless economy, Cashless policy & 500 & N.A & $\begin{array}{l}\text { Questionnai } \\
\text { re }\end{array}$ & $\begin{array}{l}\text { Descriptive } \\
\text { statistics }\end{array}$ & $\begin{array}{l}\text { cashless policy may curb cash related corruption, } \\
\text { reduce cash related robbery, therefore decrease risk of }\end{array}$ \\
\hline
\end{tabular}


(Olelewe \& E., 2014) Challenges

Facing the Sustainability of

Cashless Policy towards the

Management of the Family

Economy among Staff and

Nsukka, Chijioke

(Ovat, 2012) The Centra Bank

Nigeria's Cashless Policy in

(Mieseigha \& Ogbodo, 2013) An

Empirical Analysis of the

Nigeria's Economic Development

(Ejiofor \& Rasaki, 2012)

16 Realizing the Benefits and

in Nigeria: IT Perspective

(Matthew \& Anyanwaokoro,

2016) Cashless Economic Policy

An Nigera. A Peformance

Industry

(Okoye \& Ezejiofor, 2013) An

18 Appraisal of Cashless Econom

Nigerian Economy
(Muhibudeen \& HALADU,

Policy Tools on Money
Circulating Outside Nigerian

Odior \& Banuso 2012) Cashless
Information and

Communicatio

Educational

Nigeria

Education

International

Nigeria

Journal of

Economics and

Sustainable

Development

Nigeria Research Journal

of Finance and

Journal of

Advances in

Computer Scien

nd Technology

IOSR Journal of

Business and

Management
(IOSR-JBM)

Nigeria

Research Journal of Finance and

Accounting

International

Journal of

Business,

Econ

$\underset{\text { Scientific Journal }}{\text { European }}$
Cashless policy, challenges, economic development, mobile and internet

banking

Cashless Policy, Central Bank of

Nigeria.

Cash-based economy, Cashless paymen.

ATM, Cashless, Electronic payment

systems, Internet Banking

Cashless policy, e-payment, Paymen

channels, ROA

cashless economy, financial stability,

Policy development and Nigerian

economy

Cashless Policy, Automated Teller

Machine, Web-Based Transactions,

Mobile Banking Transaction, Point-

of-Sale, Cheques and Currency in

Cashless Banking, Nigeria, Policy
Implications regression

Descriptive

One-way

ANOVA

Descriptive

theoretical

Chi-square

(ANOVA)

Descriptive

theoretical

second

Paired

$\begin{array}{lll}2009- & \begin{array}{l}\text { secondary } \\ \text { 2014 }\end{array} & \text { Paired } \\ \text { data } & \text { Samples Test }\end{array}$

68

questionn

ANOVA and

N. 2009- Secondary Descriptive

2012

ANOVA

N.A N.A Secondary $\begin{aligned} & \text { Graph and } \\ & \text { percentile } \\ & \text { Percentages }\end{aligned}$ carrying cash, attract more foreign investors, increase
employment

Poor interconnectivity of network servers as a major challenge for efficient using of mobile banking services and some other several challenges such as insecurity personal data and online frauds still facing banks
customers which results to delay in payment.

periodic review of the policy to iron out the thorny

Positive impact and significant relationship found between cashless economy and economy developmen the other.

Despite cashless risks and glaring bottlenecks; consumers are ready to embrace the new policy of cashless economy

While some benefits associated with cashless policy which include; reduced cash handling cost; reduced risk increased convenience but still some challenges were found which include; prevalence of e-fraud,

Cyber fraud and illiteracy are major problems may help fight against money laundering, corruption, and reduce the risk of carrying cash.

Cashless Policy tools does not affect currency circulation outside Nigerian banks

Cashless Nigeria seems to have some benefits though it face some concerns over security and management of
cost savings resulting from its implementation 


\section{Objectives of the Study}

The objectives of the study are:

a- To study the impact of demonetization process on the performance of Nifty50 and its sectorial indices.

b- To compare the impact of demonetization process among sectorial indices of Nifty50.

\section{Hypotheses of the Study}

Based on the literature review and objectives of the study demonstrated above, thehypotheses of the study are:

\section{H01: There is no significant impact of demonetization process on the performance of Nifty50 and its sectorial indices.}

\section{H02: There is no significant difference of the impact of demonetization process amongsectorial indices of Nifty50}

\section{Methodology}

\subsection{Data Collection and Sample}

The study aims to investigate the impact of demonetization process on the performance of Nifty and its sectorial indices. It employs a historical data from Nifty $50 \mathrm{NSE}$ and its components of its sectorial indices. Accordingly, secondary data represented by daily basis of closing price of Nifty 50 and its sectorial indices used for this study for three months period pre and three months post demonization event. The rationale behind this choice of time limit is to study the trend of closing prices of Nifty 50 and its sectorial indices pre and post demonetization event. Further, as the demonetization process announced by the government started from 8 November 2016 and strictly specified daily limits on withdrawals from ATMs and cash till January 16, 2017; the study extended the time limit to include all demonetization procedures.

\subsection{Statistical tools and Methods}

The study employs descriptive statistics and paired sample $\mathrm{T}$ test using E views 7 software to test the impact of demonization process on the performance of Nifty 50 and its sectorial indices pre and post demonization event.

\section{Results and Discussion}

\subsection{Descriptive statistics}

Table 2 Descriptive statistics of closing prices for pre and post event. There is a sharp fall of closing prices after the demonetization event. The minimum value of the closing price post demonization process was 7908.25 which is lower than the minimum value of pre demonization process; 8204. This value was found on 26 December 2016 which may due to the end of period for exchanging of old currency that announced earlier by the government. Further, the mean of closing prices post demonization process was 8451.2742 which is comparatively lower than the mean of closing prices pre demonization process; 8630.6466. Following is Table 2 Descriptive statistics of closing prices for pre and post event. 
Table 2. Descriptive statistics of closing prices for pre and post demonization event

\begin{tabular}{|c|c|c|c|c|c|c|c|}
\hline \multirow{2}{*}{$\frac{\text { Index }}{\text { NIFTY }}$} & \multirow{2}{*}{$\begin{array}{l}\text { Period } \\
\text { Pre }\end{array}$} & \multirow{2}{*}{$\begin{array}{l}\mathrm{N} \\
90\end{array}$} & \multirow{2}{*}{$\frac{\text { Mean }}{8625.06}$} & \multirow{2}{*}{$\frac{\text { Median }}{8634.125}$} & \multicolumn{2}{|c|}{ Maximum Minimum } & \multirow{2}{*}{$\frac{\text { Std. Deviation }}{150.4385}$} \\
\hline & & & & & 8952.5 & 8127.85 & \\
\hline & Post & 90 & 8458.781 & 8394.75 & 9160.05 & 7908.25 & 361.3946 \\
\hline \multirow[t]{2}{*}{ NIFTY Auto Index } & Pre & 90 & 9735.547 & 9881.675 & 10458.65 & 8618.85 & 462.7495 \\
\hline & Post & 90 & 9472.689 & 9629.225 & 10191.95 & 8681.6 & 412.6019 \\
\hline \multirow[t]{2}{*}{ NIFTY Bank Index } & Pre & 90 & 19207.43 & 19294.98 & 20426.2 & 17561.55 & 603.2667 \\
\hline & Post & 90 & 19307.32 & 19077.45 & 21249.9 & 17655.55 & 1073.056 \\
\hline \multirow[t]{2}{*}{ NIFTY energy Index } & Pre & 90 & 9546.246 & 9538 & 10201.65 & 8512.9 & 411.3213 \\
\hline & Post & 90 & 10492.26 & 10458.95 & 11573.85 & 9657.8 & 563.7843 \\
\hline \multicolumn{2}{|c|}{ NIFTY Financial ServicesPre } & 90 & 7898.667 & 7935.425 & 8385.85 & 7157.25 & 256.7424 \\
\hline Index & Post & 90 & 7796.405 & 7627.325 & 8601.15 & 7175.35 & 417.1547 \\
\hline \multirow[t]{2}{*}{ NIFTY FMCG Index } & Pre & 90 & 22010.44 & 21999.88 & 23186.15 & 21195.9 & 435.2032 \\
\hline & Post & 90 & 21359.1 & 21215.33 & 23500.25 & 19592.85 & 1104.791 \\
\hline \multirow[t]{2}{*}{ NIFTY IT Index } & Pre & 90 & 10599.91 & 10530.8 & 11222.2 & 9809.75 & 385.6876 \\
\hline & Post & 90 & 10212.44 & 10198.53 & 10900.75 & 9434.6 & 377.0811 \\
\hline \multirow[t]{2}{*}{ NIFTY Media Index } & Pre & 90 & 2850.796 & 2860.925 & 3127.8 & 2524 & 133.6936 \\
\hline & Post & 90 & 2774.462 & 2747.425 & 3113.8 & 2493.8 & 188.8761 \\
\hline \multirow{2}{*}{ NIFTY Metal Index } & Pre & 90 & 2523.703 & 2541.275 & 2781 & 2115.85 & 146.6302 \\
\hline & Post & 90 & 2905.716 & 2935.1 & 3189.4 & 2536.2 & 192.6657 \\
\hline \multirow[t]{2}{*}{ NIFTY Pharma Index } & Pre & 90 & 11527.99 & 11561.08 & 11936.65 & 10606 & 236.5773 \\
\hline & Post & 90 & 10570.92 & 10561.25 & 11132.05 & 9889.3 & 271.0782 \\
\hline \multicolumn{2}{|c|}{ NIFTY Private Bank IndexPre } & 90 & 10784.63 & 10779.48 & 11501.2 & 9887.9 & 309.5088 \\
\hline & Post & 90 & 10685.56 & 10537.75 & 11786.7 & 9743.15 & 613.7194 \\
\hline \multirow{2}{*}{ NIFTY PSU Bank Index } & Pre & 90 & 3035.278 & 3078.325 & 3323.35 & 2693.2 & 159.0773 \\
\hline & Post & 90 & 3191.288 & 3181.775 & 3450.45 & 2910.65 & 144.272 \\
\hline \multirow[t]{2}{*}{ NIFTY Realty Index } & Pre & 90 & 206.4228 & 206.525 & 214.65 & 189.75 & 4.413699 \\
\hline & Post & 90 & 179.3444 & 178.9 & 208 & 153.85 & 14.57299 \\
\hline
\end{tabular}

To carry forward the analysis, following is a technical analysis of Nifty 50 and its sectorial indices:

\section{6-1-1. Nifty 50}

Figure 1 shows that there is a sharp decrease of closing prices of Nifty 50 after the demonetization event which took place on 8 November 2016. The closing prices post demonetization event started to decrease from 9 November. On 8 November the price was 8543.55 ₹ but it fall to 8432 ₹ on 9 November. It continuously declined to reach the lowest level on 21 December 2016 which was 7908.25 ₹. Gradually, the closing price started to increase after 26 December which may due to relaxation of the period and the massages sent by the government to control the demonetization process.

\section{6-1-2. Sectorial Indices of Nifty50:}

6-1-2-1. Nifty Auto Index:

Figure 2 shows the trend of closing prices of the Automobile sector of Nifty

50. The closing prices started to decrease after 8 November 2016 but the index started to increase after 28 December 2016.

\section{6-1-2-2. Nifty Bank Index:}

As shown in figure 3, differently from other sectorial indices of Nifty 50, the Bank sectorial index increased after 8 November 2016 and continue to increase for two days after demonetization event. Overall the index slightly decreased after three days of demonetization announcement and continue to decrease slightly till the end of Jan. 2017. From 27 January 2016, the index recovered its prices and started increasing.

\section{6-1-2-3. Nifty 50 Energy Index:}


Figure 4 shows the trend of Nifty 50 Energy index closing prices. It shows that Energy index slightly decreased. Similarly to Bank index, Nifty 50 Energy index closing prices increased after 8 Nov. 2016 and continue to increase for two days after demonetization event but it recovered its prices on 28 Nov. 2016. Since then, the index started to gain till the end of the period of this study except in two days at the end of November which decreased slightly.

\section{6-1-2-4. Nifty Financial Services Index:}

As shown in figure 5, Nifty Financial Services index had both increasing and decreasing trend in the pre demonetization event, but after post demonization the index started to decrease from 8093 ₹ on 10 Nov 2016 to 7917 ₹ on 31 Jan. 2017. On the next trading day; 1 Feb. 2017 the index started to gain which reached to a peak point of 8601 ₹ during the period of this study.

\section{6-1-2-5. Nifty FMCG:}

Comparing the minimum and maximum closing prices of Nifty FMCG during pre and post demonetization, it is notably to mention that the minimum value in the pre demonetization period was 21196 ₹ against 19592 ₹ in the post demonetization period. Similarly, the maximum prices in the pre demonization was 23186 ₹ against $23500 ₹$ in the post demonization. The index had slight decrease after demonization but it has composed its prices especially at the end of December 2016. Figure 6 illustrates the trend of Nifty FMCG.

\section{6-1-2-6. Nifty IT:}

Differently from other indices of Nifty 50, comparing the minimum and maximum closing prices of Nifty IT during pre and post demonetization, it is worthy to notice that the minimum value in the pre demonetization period was 9809 ₹ against 9434 ₹ in the post demonetization period. Similarly, the maximum prices in the pre demonization was 11222 ₹ against 10900 ₹ in the post demonization. Accordingly, the closing prices in the post demonetization period are comparatively less than pre demonization. Figure 7 demonstrates the trend of Nifty IT.

\section{6-1-2-7. Nifty Media:}

Figure 8 shows that Nifty Media has slight drop starting from 11 Nov. 2016 till 25 Jan. 2017. The index had the lowest value at the post demonization period which was 2494 ₹.

\section{6-1-2-8. Nifty Metal:}

Figure 9 demonstrates that Nifty Metal did not change after demonetization event as compared to the pre demonetization event. The lowest price of the index was $2115 ₹$ on 25 June 2016 against $2536 ₹$ at the post demonetization event.

\section{6-1-2-9. Nifty Pharma:}

This index decreased from minimum 10606 ₹ at the pre demonetization event to 9889 ₹ at post demonetization event. Further, the index dropped form maximum $11937 ₹$ at the pre demonetization event to maximum 11132 ₹ at post demonetization event. Figure 10 provides the trend of Nifty Pharma.

Figure 1. Nifty 50 Index

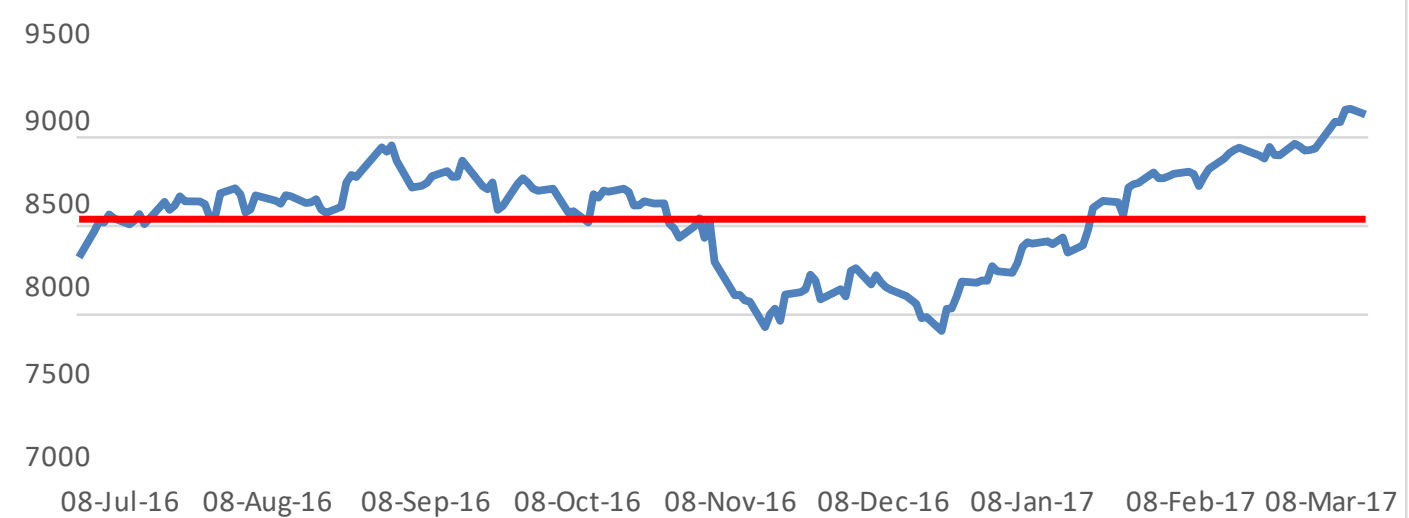



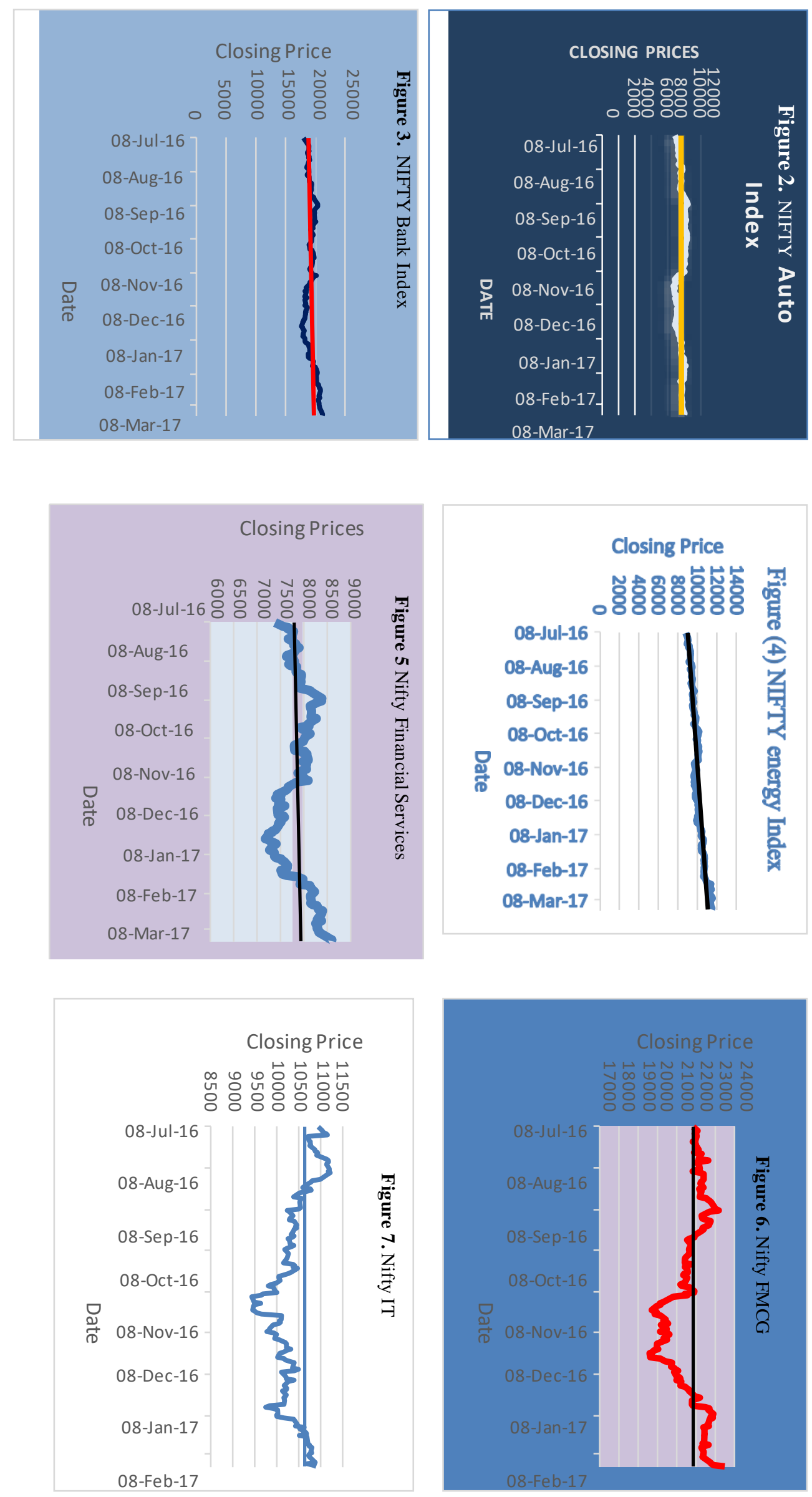

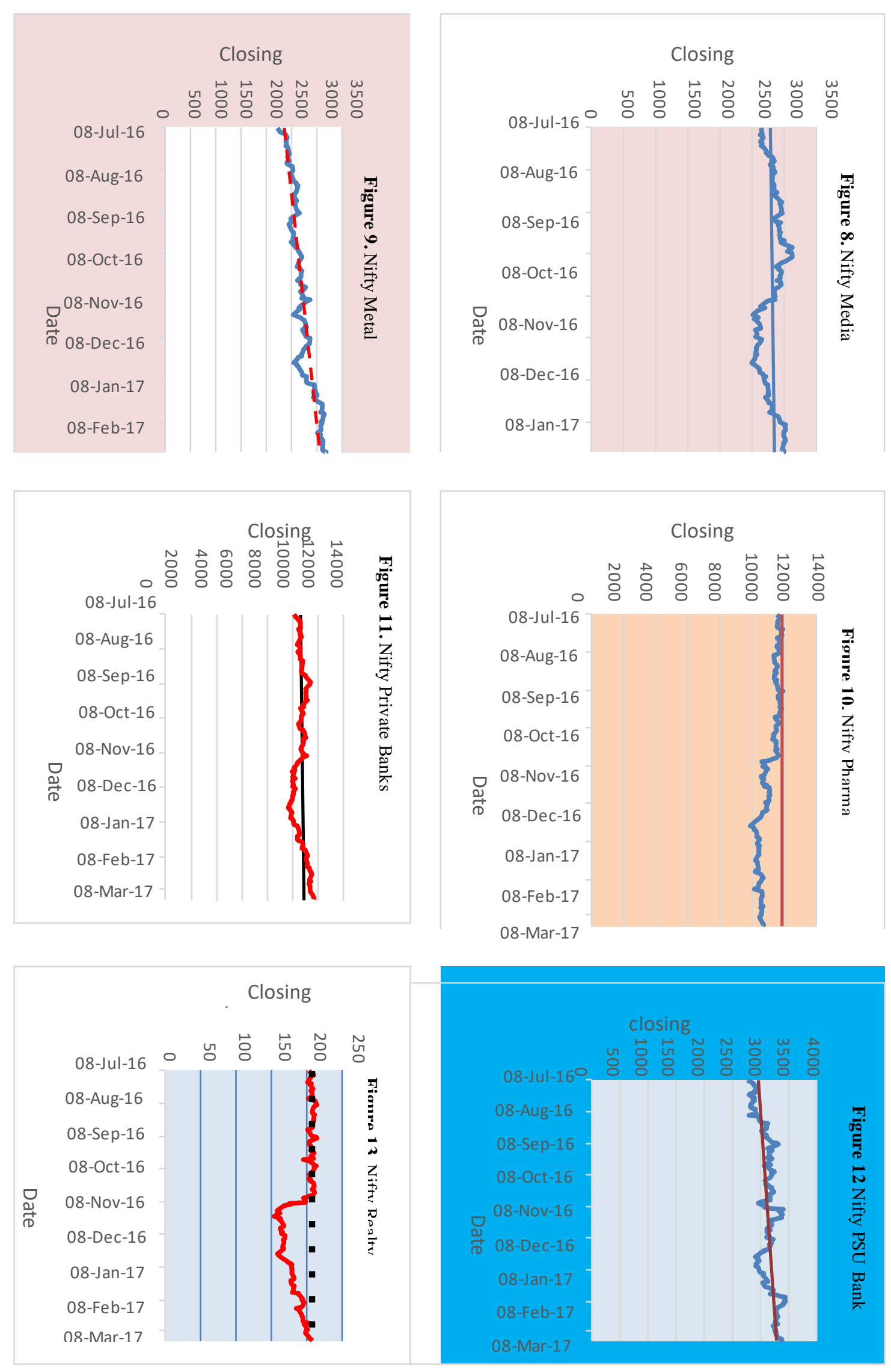


\section{6-1-2-10. Nifty Private Banks:}

Figure 11 shows a slight change in this index which decreased from minimum 9888 ₹ the pre demonetization event to 9743 ₹ at post demonetization event but the index composed its losses and changed from maximum 11501 ₹ in the pre demonetization event to maximum 11787 ₹ in the post demonetization event.

\section{6-1-2-11. Nifty PSU Bank:}

Figure 12 illustrates that this index did not drop after demonetization. Rather than dropping, the index changed from minimum 2623 ₹ at the pre demonetization event to $2910 ₹$ at post demonetization event and from maximum 3323 ₹ at the pre demonetization event to maximum $3450 ₹$ at post demonetization event.

\section{6-1-2-12. Nifty Realty:}

Figure 13 shows a slight change in this index which decreased from minimum $190 ₹$ at the pre demonetization event to 154 ₹ at post demonetization event. Further, it is decreased from maximum $215 ₹$ at the pre demonetization event to maximum 208 ₹ at post demonetization event.

\subsection{Paired sample T test}

Table 3 demonstrates Paired sample $\mathrm{T}$ test of Nifty and its sectorial indices for pre and post demonetization event. The results reveal that there is a high significance level on the impact of demonetization on the closing prices of Nifty 50 post demonetization period as compared to the pre demonetization period. Irrespective of the impact of the othervariables that may affect the closing prices of Nifty 50 after demonetization period, the results reveal that $\mathrm{P}$ value is less than 0.05 ( $\mathrm{P}<$ 0.05 ) which is highly significant at the level of $95 \%$ confidence level. This result leads to reject the null hypothesis (Ho1) which stated that "There is no significant impact of demonetization process on the performance Nifty 50 and its sectorial indices". The results have proved that there is a significant difference in the pre and post demonetization periods and demonetization event has left some impact on the stock market indices.

Table 3. Paired sample T test of nifty and its sectorial indices for pre and post demonetization event

\begin{tabular}{|c|c|c|c|c|}
\hline Pre and post & $\begin{array}{l}\text { Mean } \\
\text { Diff. }\end{array}$ & S.D. of diff. & t-statistic & Prob. \\
\hline Nifty post - Nifty Pre & -166.28 & 362.92 & -4.35 & 0.0000 \\
\hline NIFTY Auto Index post - NIFTY Auto Index Pre & -262.86 & 321.45 & -7.76 & 0.0000 \\
\hline $\begin{array}{l}\text { NIFTY Bank Index post - NIFTY Bank Index Pre } \\
\text { NIFTY energy Index post - NIFTY energy Index Pre }\end{array}$ & $\begin{array}{l}99.89 \\
946.01\end{array}$ & $\begin{array}{c}1072.26 \\
283.62\end{array}$ & $\begin{array}{c}0.88 \\
31.64\end{array}$ & $\begin{array}{l}0.3792 \\
0.0000\end{array}$ \\
\hline $\begin{array}{l}\text { NIFTY Financial Services Index post - NIFTY Financial } \\
\text { Services Index Pre }\end{array}$ & -102.26 & 424.68 & -2.28 & 0.0247 \\
\hline NIFTY FMCG Index post - NIFTY FMCG Index Pre & -651.35 & 1327.14 & -4.66 & 0.0000 \\
\hline NIFTY IT Index post - NIFTY IT Index Pre & -387.47 & 701.59 & -5.24 & 0.0000 \\
\hline NIFTY Media Index post - NIFTY Media Index Pre & -76.33 & 150.31 & -4.82 & 0.0000 \\
\hline NIFTY Metal Index post - NIFTY Metal Index Pre & 382.01 & 156.56 & 23.15 & 0.0000 \\
\hline NIFTY Pharma Index post - NIFTY Pharma Index Pre & -957.06 & 361.97 & -25.08 & 0.0000 \\
\hline NIFTY Private Bank Index post - NIFTY Private Bank Index Pre & -99.07 & 622.46 & -1.51 & 0.1346 \\
\hline NIFTY PSU Bank Index post - NIFTY PSU Bank Index Pre & 156.01 & $\begin{array}{l}206.681 \\
6\end{array}$ & 7.16 & 0.0000 \\
\hline NIFTY Realty Index post - NIFTY Realty Index Pre & -27.08 & $\begin{array}{l}15.6015 \\
5\end{array}$ & -16.47 & 0.0000 \\
\hline
\end{tabular}




\subsection{Analysis of variance (Anova):}

Table 4. Analysis of Variance of Nifty and its Sectorial Indices for Post Demonetization

Event

Test for Equality of Means Between Series

Date: 03/29/17 Time: $17: 12$

Sample: 6/28/2016 11/08/2016

Included observations: 90

\begin{tabular}{|c|c|c|c|}
\hline Method & $\mathrm{df}$ & Value & Probability \\
\hline Anova F-test & $\begin{array}{l}(12,1157) \\
(12,\end{array}$ & 11557.25 & 0.0000 \\
\hline $\begin{array}{l}\text { Welch F-test* } \\
\text { Analy sis of Variance }\end{array}$ & 417.45) & 42335.26 & 0.0000 \\
\hline $\begin{array}{l}\text { Source of Variation } \\
\text { Between }\end{array}$ & df & $\begin{array}{l}\text { Sum of Sq. } \\
4.10\end{array}$ & $\begin{array}{l}\text { Mean Sq. } \\
3.42\end{array}$ \\
\hline Within & 1157 & 3.42 & 295849.4 \\
\hline Total & 1169 & 4.14 & 35391569 \\
\hline
\end{tabular}

From the above table the results indicate that the differences between the groups are

4.10 with a mean of 3.42 but the differences within the groups are 3.42 with a mean

of 29585 . The $\mathrm{P}$ value is less than 0.05 which leads to reject the Null hypothesis

which stated that there is no significant differences among the sectorial indices of

Nifty50.

\section{Conclusion and Recommendations}

The study aimed to investigate the impact of demonetization process on the performance of Nifty 50 and its sectorial indices. The study used pre and post demonetization historical data of Nifty from 28 June 2016 up to 20 March 2017. It Employed paired sample T test and descriptive statistics. The study found that Nifty 50 dropped after the announcement of demonetization. Further, the results reveal that $\mathrm{P}$ value of paired sample $\mathrm{T}$ test is less than $0.01(\mathrm{P}<0.01)$ which is highly significant at the level of $99 \%$ confidence level. Furthermore, the results reveal that most of Sectorial Indices of Nifty 50 sloped down post demonetization event and the significance of the statistical results are varied from one sector to another. The study has recommended the following:

1 - It is recommended that periodic review of the policy should be made to iron out the negative impact of demonetization.

2- It is imperative to evaluate the impact of demonetization on the short, medium, and long run to avoid any grey areas for any future policy regarding cashless economy.

3 - Future studies may focus individually on the sectors of Nifty 50 to investigate deeply how demonetization affected every individual sector.

The study is limited to three months pre and tree months post demonetization period. Also, other variables have not been investigated in this study, it is only limited to the impact of demonetization process on Nifty 50 and its sectorial indices. 


\section{References}

[1] Adu, C. A. (2016). Cashless policy and its effects on the Nigerian economy. European Journal of Business, Economics and Accountancy, 4(2), 81-88.

[2] Bayero, M. A. (2015). Effects of cashless economy policy on financial inclusion in Nigeria: An exploratory study. Procedia -Social and Behavioral Sciences Global Conference on Business \& Social Science, 172, 49-56. http://doi.org/10.1016/j.sbspro.2015.01.334

[3] Bhardwaj, A., Narayan, Y., Vanraj, Pawan, \& Dutta, M. (2015). Sentiment Analysis for Indian Stock Market Prediction Using Sensex and Nifty. Procedia Computer Science, 4thInternational Conference on Eco-Friendly Computing and Communication Systems Sentiment, 70, 85-91. http://doi.org/10.1016/j.procs.2015.10.043

[4] Chelladurai, M., \& V.Sornaganesh. (2016). Demonetisation, unified payment interface \& cashless economy. International Journal of Informative \& Futuristic Research, 4(3), 5654-5662.

[5] Ejiofor, V. E., \& Rasaki, J. O. (2012). Realising the benefits and challenges of cashless economy in Nigeria: it perspective. International Journal of Advances in Computer Science and Technology, 1(1), 7-13.

[6] Emengini, S. E., \& Alio, felix C. (2014). Cashless economy and financial statement reporting in Nigeria. European Journal of Accounting Auditing and Finance Research, 2(3), 1-9.

[7] Ezeamama, M. C., Joseph, N., Marire, M. I., \& Mgbodile, C. C. (2014). The Impact of Central Bank of Nigeria Cashless Policy in Nigeria Economy. IOSR Journal of Business and Management (IOSR-JBM), 16(12), 84-95.

[8] Governmant of India, Ministry of Finance, D. of E. A. E. D. (2017). Economic Survey 201617 .

[9] Government of India, Ministry of Finance, Department of Economic Affairs, E. D. (2017). Demonetisation: To Deify or Demonize? Economic Survey.

[10] Kaur, M. (2017). Demonetization : impact on cashless payemnt system. International Journal of Science Technology and Management, 6(1), 144-149.

[11] M Allirajan. (2017). India's currency-GDP ratio highest among BRICS nations. The Times of India, Http://timesofindia.indiatimes.com/business/india-business/Indias- Currency-GDP-RatioHighest-among-BRICS-nations/articleshow/55576351.cms, p. retrived on 17/03/2017.

[12] Matthew, O. M., \& Anyanwaokoro, M. (2016). Cashless Economic Policy in Nigeria: A Performance Appraisal of The Banking Industry . IOSR Journal of Business and Management (IOSR-JBM), 18(10), 1-17. http://doi.org/10.9790/487X-1810030117

[13] Mieseigha, E. G., \& Ogbodo, U. K. (2013). An Empirical Analysis of the Benefits of Cashless Economy on Nigeria's Economic Development. Research Journal of Finance and Accounting, 4(17), 11-16.

[14] Muhibudeen, L., \& HALADU, A. (2015). The impact of cashless policy tools on money circulating outside Nigerian banks. International Journal of Business, Economics and Law, 8(3), $47-$ 52 .

[15] Muyiwa, O., Tunmibi, S., \& A.T, J.-D. (2013). Impact of Cashless Economy in Nigeria By Impact of Cashless Economy in Nigeria. Greener Journal of Internet, Information and Communication Systems, 1(2), 40-43. 
[16] National Institute of Public Finance and Policy New Delhi. (2016). Demonetisation : Impact on the Economy.

[17] Odior, E. S., \& Banuso, F. B. (2012). Cashless banking in Nigeria : challenges , benefits and policy implications. European Scientific Journal, 8(12), 289-316.

[18] Okoye, P. V. C., \& Ezejiofor, R. (2013). An Appraisal of Cashless Economy Policy in Development of Nigerian Economy. Research Journal of Finance and Accounting, 4(7), 237-253.

[19] Olelewe, C. J., \& E., N. (2014). Challenges facing the sustainability of cashless policy towards the management of the family economy among staff and students of university of Nigeria, Nsukka Chijioke. Educational Research Internationa, 3(April), 56-65.

[20] Osazevbaru, H. O., \& Yomere, G. O. (2015). Benefits and challenges of Nigeria's cash- less policy. Kuwait Chapter of Arabian Journal of Business and Management Review, 4(9), 1-10.

[21] Ovat, O. O. (2012). The Central Bank of Nigeria's Cashless Policy in Nigeria: Benefits and Challenges. Journal of Economics and Sustainable Development, 3(14), 128- 134.

[22] Singh, P., \& Singh, V. (2016). Impact of demonetization on Indian economy. International Journal of Science Technology and Management, 5(12), 625-635.

[23] Worthington, S. (2014). The cashless society. International Journal of Retail \& Distribution Management, 23(7), 31-40. 